\title{
The limits of the administration of memory in settler colonial societies:
}

\author{
The Australian case
}

\section{Introduction}

Settler colonial societies provide particular challenges for the administration of memory. The nature of the settler colonial project, driven by a logic requiring the 'elimination' of Indigenous peoples (Wolfe, 1999, p. 2), relies on the active and forceful domination of an invaded territory's original inhabitants through the repression of their culture, identity and history. This very fact, however, challenges the legitimacy of the colonial mission and the development of settler society. This in turn feeds a somewhat circular pattern to the administration of settler colonial memory. As the memory of historical colonial brutality feeds a sense of moral illegitimacy among contemporary policy actors, it in turn drives a desire to draw a line under the past - to pursue a moment of colonial 'completion.'. Public policy that focuses on historical memory seeks a rapid conclusion to public discussion, effectively downplaying or erasing Indigenous grievances against the settler state. In response, Indigenous people seek to keep open public debate, asserting their dissatisfaction with the settler policy response. Thus, the cycle begins again. This article suggests a way out of this circularity. Rather than settler states seeking to administer memory in order to deprive counter-veiling memories of public oxygen, a more agonistic approach would see the articulation of those counterveiling memories as a success rather than a failure of public administration.

As I have argued elsewhere (Maddison 2016), the key political dynamic of settler colonialism is the endless cycling of attempts to eliminate or absorb the Indigenous population, which is met with Indigenous resistance. This political dynamic has been a constituent component of all settler colonial regimes, including Australia, since their various moments of invasion. In Australia, contestation and resistance by Aboriginal and Torres Strait Islander peoples came into particular focus in the second half of the twentieth century, as the Indigenous rights movement began to articulate their claims as colonised peoples demanding recognition of their sovereignty rather than recognition as an excluded minority seeking civil inclusion (McGregor, 2011, p. 164). This, combined with efforts by Aboriginal people from at least the 1980s until the present, to challenge the official version of Australia's history by insisting on acknowledgement 
of their prior occupation, their direct familial experiences of invasion, dispossession and racism, and their ongoing struggles for recognition, reparation, and survival (Curthoys, 2003, Maddison, 2011), has produced a fragile national identity that struggles to develop effective memory policy.

The deep resistance to acknowledging the foundational illegitimacy of the Australian settler state fuels a limited approach to the administration of memory, which has generally been framed under formal policies of 'reconciliation'. In what follows I first examine the challenges inherent to memory policy in settler colonial societies before reviewing three attempts at administering memory in Australia through (informal) truth commissions, a formal reconciliation process, and a national apology to the families affected by past policies of removing Aboriginal and Torres Strait Islander children from their families. In each instance, it is evident that the settler desire to reclaim its moral legitimacy was confounded by the continued presence and resistance of Indigenous peoples and by the fact that moral engagement with these peoples 'resists closure' in the way the settler state desires (Rose, 2004, pp. 13-14). This recognition of the ongoing nature of the settler colonial project leads me to propose instead a more agonistic orientation to the administration of memory in settler colonial societies, predicated on the persistence rather than the resolution of conflict. Such an approach would upend the standard approach to the implementation of reconciliation policies, seeing them not as opportunities for the closure of debate, but rather as a means of keeping open political space in which contested views about the past may be engaged.

\section{Settler colonial theory and the problem of history}

The developing field of settler colonial studies underscores the significance of the continuing and permanent settler presence in the group of 'Anglo' nations that avoided the 'decolonising gestures' experienced in the extractive colonies of South Asia, South America, and much of Africa (Cavanagh, 2012, p. 24). Where the extractive colonies experienced periods of (often problematic) decolonisation and democratisation, settler colonial states maintain their intention to permanently displace indigenous peoples from their territories, without aspiration towards any form of structural decolonisation (Strakosch and Macoun, 2012, p. 41).

Patrick Wolfe's seminal formulation of settler colonialism underscores the fact that 
settler colonies were and are premised on the elimination of Indigenous societies (Wolfe, 1999, p. 2). Elimination may occur through physical violence or assimilation. Indeed, elimination has been pursued through policies including the dispossession Indigenous peoples from their lands; the destruction of Indigenous families and communities through policies of containment and child removal; the inclusion or recognition of Indigenous polities within the settler state; and even the negotiation of treaties or other agreements that ostensibly 'erase the political distinctions between coloniser and colonised' (Strakosch and Macoun 2012: 45). Thus, although the settler state may not necessarily continue to pursue the physical death of Indigenous people per se (although violent death is intrinsic to colonialism in the past and present), it will continue to seek the social and political death of Indigenous peoples as such (Battell Lowman and Barker 2015: 30). Elimination is not then some kind of one-off occurrence that may later be overcome or superseded, but is, more fundamentally, an 'organising principle' of the settler state (Wolfe 2016: 33).

Apparently benign or progressive policies, like reconciliation, may seem to contradict this argument. Reconciliation, in particular, may appear to be a policy framework that privileges remembering, rather than erasing, the experiences of Indigenous peoples. Australia provides a useful case for understanding why and how reconciliation policy is in fact also driven by a logic of elimination. Reconciliation is seen as an opportunity to draw Indigenous peoples into the national community, thereby eliminating their political difference. As in other settler colonial contexts, reconciliation in Australia was cloaked in policy discourse emphasising unity and nation-building, aspiring to 'replace past division with a new, shared sense of nationhood', creating a 'harmonious and integrated society' (Bashir and Kymlicka, 2008, p. 15). Reconciliation in Australia thus provided Aboriginal and Torres Strait Islander peoples only with 'a right to be incorporated into the Australian nation but not a right to refuse' (Short 2005: 274). The administration of reconciliation policy in settler contexts thus begins from the assumption that the settler state will and should maintain authority over indigenous peoples, in effect reaffirming the legitimacy of the settler order without redressing the core injustices of colonialism (Kymlicka, 2011, p. 322, see also Maddison and Shepherd, 2014). 
In opposition to the settlers' position, many Indigenous actors approach the administration of memory for quite different ends. In Australia, Aboriginal and Torres Strait Islander peoples continue to challenge the permanency and legitimacy of invasion and settlement, and instead demand that the settler society recognise the existence and continued sovereignty of self-determining Indigenous groups (Woolford, 2010, p. 138). As in other settler colonial orders, Aboriginal and Torres Strait Islander peoples in Australia have contested the settler colonial presence, along with settler dominance of the social, economic, and political orders, from invasion throughout the twentieth and twenty-first centuries and into the present day.

This dynamic of contestation has important effects on the administration of memory. Policy, including reconciliation policy, remains 'a crucial site of political encounter' in the settler colonial context (Strakosch, 2015, p. 2). Efforts by the settler state to create policy that appears benevolent in fact offer no path towards decolonisation as they remain caught in the settler's eliminatory logic. Both Indigenous people and settler states may view the creation of memory policy as a desirable goal, yet they are likely to pursue this goal for quite different ends. The moments of 'unease and disruption' produced by Indigenous resistance have had limited effect on official efforts to reconcile the settler colonial past (Howard-Wagner, 2012, p. 227). Instead these moments attest to the 'structural temporality' of settler colonialism, which effectively obscures the 'vanishing endpoint' of its own resolution (Strakosch and Macoun, 2012, pp. 51-2). The settler colonial imaginary still envisages the nation on a pathway towards a more 'settled' post-colonial future that has 'reconciled' past injustice (Bhandar 2007, pp. 934). This dynamic informs a reductive approach to the administration of memory in which settler societies seek to 'draw a line through history', emphasising that abuses and wrongdoing are 'firmly in the past' (Jung, 2011, p. 231).

In contrast, Indigenous peoples may pursue reconciliation policies in order to open up public discourse both about past wrongs and about the sovereignty and collective rights they contest in the present. Indigenous leaders may see the administration of memory as an opportunity to build 'not a wall but a bridge', to 'draw history into the present, and to draw connections between past policy, present policy, and present injustices', thereby highlighting the complex ways in which 'present policies reinscribe historical injustices and relations of oppression' (Jung, 2011, p. 217). What Indigenous peoples 
seek is a transformation of the settler society such that their sovereignty as distinct and self-governing peoples is recognised. As Courtney Jung (2011, p. 226) has suggested, administering memory through acts such as apologies and truth commissions 'offer opportunities for reinscribing the responsibility of states toward their indigenous populations, empowering indigenous communities, responding to indigenous demands to be heard, and rewriting history'. The settler state sees a different opportunity: the elimination of Indigenous political difference through new policy discourse emphasising the harmony and unity of the nation.

\section{The administration of memory in settler colonial Australia}

Like other settler colonial states, Australia has demonstrated strong resistance to addressing the deeper, more complex aspects of colonial injustice. Broadly speaking, the administration of memory in Australia has rejected calls for more radical forms of political transformation, thereby entrenching the structural violence of colonisation. In this section I consider three attempts at administering memory for future co-existence, highlighting their shortcomings with regard to Indigenous aspirations. In each example, it is possible to observe a similar pattern: policy initiatives are announced in response to Indigenous activism and contestation; from the outset the initiative is constrained and delimited by the settler refusal to fully acknowledge the past; the eventual policy outcome is perceived as disappointing — recommendations are not acted upon, actions (such as compensation) are refused, and so on. This dynamic-contestation, policy response, disappointment - in turn fuels the next round of policy contestation and debate as disaffected Indigenous parties seek more effective response to their claims.

The first attempt at the more productive administration of memory to be examined here is the conduct of two inquiries that closely resemble truth commissions ${ }^{1}$ : the Royal Commission into Aboriginal Deaths in Custody (RCIADIC) and the Inquiry into the Separation of Aboriginal Children from their Families (often referred to as the Stolen

\footnotetext{
${ }^{1}$ I am using Brandon Hamber's definition of truth commissions as 'temporary ad hoc inquiries into particular events that are officially sanctioned or authorised by the state' and that 'typically focus on patterns of events or a series of violations over a specific period of time' (Hamber, 'Transitional Justice and Intergroup Conflict', 329).
} 
Generations $^{2}$ inquiry), and its report titled Bringing them Home (BTH). Truth commissions seek to end denial about the impact, effects, and extent of systematic and historical violence, challenging accepted understandings of the past by establishing a shared historical record of past violence and abuses (Leebaw 2008, p. 107). The testimony of victims of specific harms is used to (re)construct 'an official narrative of a country's violent and repressive past' in an effort to 'restore the national community' (Renner 2012, p. 56). In settler colonial societies, however, inquiries and inquests into Indigenous deaths (including deaths in custody) have tended to 'install white settler superiority', maintaining an image of the benevolent settler society that has tried but failed to save a dying race (Razack 2015: 9).

Both the Royal Commission into Aboriginal Deaths in Custody and the Stolen Generations inquiry were commissioned specifically to investigate forms of historic violence against Indigenous people and make policy recommendations intended to address their contemporary impacts. Both had been sought by Aboriginal and Torres Strait Islander peoples and were welcomed by them, reflecting the Indigenous desire to 'inscribe their own historical experience in the history of the nation' without diminishing their demands for the recognition of sovereignty (Jung 2011, p. 242).

The Royal Commission into Aboriginal Deaths in Custody undertook what was described in its final report as a 'very rigorous' process of inquiry into 99 deaths in custody that occurred between 1 January 1980 and 31 May 1989. The process included the subpoena of the records of all 99 deaths under investigation, from the relevant custodial and police authorities, courts and hospitals, the coroners' records, all departments having specific dealings with Aboriginal people, and where appropriate, from legal aid offices. The subsequent hearings were open to the public, and in many cases, were long and intense, with transcripts running to over one thousand pages. In almost all cases the family of the deceased person was legally represented at the hearing. The final report concluded that while there were very few cases in which 'deliberate violence on the part of custodians' could be substantiated (RCIADIC Vol 1

\footnotetext{
${ }^{2}$ Coined by historian Peter Read in the 1980s, the term 'stolen generation' has, according to Robert Manne, taken on a similar significance for Indigenous Australians as the term 'the Holocaust' has for Jews (Manne 2001, p. 82).
} 
Ch 3), the systemic racism and appalling treatment often endured by Aboriginal and Torres Strait Islander people both before and during their interactions with the police and justice system, along with the gross deficiencies in the standard of care afforded to many of the deceased, were causatively linked to the high rates of death in custody. Although the final report, released in April 1991, found that the immediate causes of the deaths that had been investigated did not include the 'unlawful, deliberate killing of Aboriginal prisoners by police and prison officers', it painted a shocking picture of the socioeconomic conditions that were contributing to the significant over-representation of Indigenous people in the justice system.

The report emphasised the need for widespread reform in the relationship between Aboriginal and Torres Strait Islander and the Australian state, with a focus on land reform, self-determination, and improvements in the provision of basic services. Indeed, the RCIADIC report attended precisely to the need articulated by Paige Arthur (2012, pp. 43-44), that if a truth commission 'wants to contribute to indigenous peoples' self-determination and political rights, then it must put individual human rights violations in their historical and social contexts', taking special care to explain how a lack of self-determination 'created conditions for state-led human rights abuse'. The Commission's final recommendations also argued that, in order to break the pattern of Indigenous exclusion and marginalisation that had contributed to the deaths in custody, 'reconciliation between the Aboriginal and non-Aboriginal communities in Australia must be achieved if community division, discord and injustice to Aboriginal people are to be avoided' (RCIADIC 38.32). While the majority of recommendations contained in the report have never been implemented the federal government did in fact introduce a formal policy of reconciliation, outlined below. It is noted, however, that in the absence of addressing the recommendations requiring structural reform to the relationship between Aboriginal and Torres Strait Islander peoples and the state, the number of Aboriginal deaths in custody had not declined, and the over representation of Aboriginal and Torres Strait Islander people in custody has increased. As one of the original commissioners has noted, the 'vicious cycle' of Indigenous engagement with the criminal justice system remains unchanged (Dodson quoted in Henderson, 2016).

Following shortly after the Royal Commission came a second informal truth commission; the Inquiry into the Separation of Aboriginal and Torres Strait Islander 
Children from Their Families. Undertaken in the mid 1990s this inquiry took oral and written testimony from 535 'victims', including through an extensive program of hearings in every capital city and in many regional and smaller centres. The resulting report, Bringing them Home, concluded that, 'between one in three and one in ten Indigenous children were forcibly removed from their families and communities in the period from approximately 1910 until 1970' (Human Rights and Equal Opportunities Commission, 1997, pp. 36-7). The report recommended that all Australian governments should officially and publicly apologise to the Stolen Generations for the harms done by past policies. The Howard Government (elected in 1996), however, took issue with the report and vehemently rejected the idea of a government apology. The government set about deconstructing the report's findings through arguments that have been described as 'pedantic and tactless in almost equal measure' (Manne, 2001, p. 83), rejecting not only the call for an apology but also recommendations from the report relating to the incorporation of critical findings into school curricula, arguing that such measures would encourage separatism and guilt (Gunstone 2009, p. 78).

The report also prompted a furious national debate, which became known as the 'history wars.' In the years that followed, historians on both sides of the 'wars' debated whether there had ever been a deliberate policy to eradicate Indigenous populations in the colony; where and whether massacres had taken place; the number of deaths that had resulted; whether or not smallpox had been introduced to Australia by the British and if so whether this had been deliberate; and the number of Aboriginal children that had been removed from their families by missionaries and government agencies and the circumstances of their removal (see Reynolds 1999, Windschuttle 2002, Manne 2003, and Macintyre and Clark 2003 inter alia). By the mid 1990s public discussion had become dominated by debate about Australian colonial history, with a renewed assertion of the modern-day benefits accruing to all Australian as a result of colonisation. A new phrase, the 'black armband view of history,' advanced in an essay by historian Geoffrey Blainey (1993), came into use, contending that the 'balance sheet of Australian history' showed more to be celebrated than regretted. This view was also taken up by Prime Minister Howard who argued that where the 'black armband' view reflected a belief 'that most Australian history since 1788 has been little more than a disgraceful story of imperialism, exploitation, racism, sexism and other forms of 
discrimination' in fact the history of Australia was one of 'heroic achievement' (Howard, 1996).

Official government resistance to the Bringing them Home findings, along with the heat of the public debates that followed, are emblematic of the cycle of contestation that I am suggesting is typical of memory politics in settler colonial societies. On the one hand, the Australian truth commissions did play a role in opening up political space for debate about settler colonial history and memory, ensuring that the issue of child removal, which had not been seen as significant enough to warrant mention in the preamble to the Australian reconciliation legislation (passed in 1991), became central to the reconciliation process (Short, 2008, p. 99). On the other hand, however, settler political intransigence ensured that aside from a grudging acceptance of the narrative concerning Australia's Stolen Generations, Australia's truth-telling processes did not foster any more significant engagement about the continued coexistence of Aboriginal and Torres Strait Islander peoples and the Australian settler state. Not only do Indigenous and non-Indigenous versions of history in Australia remain as far apart as ever (Reynolds, 2013, p. 256, Birch, 2007, p. 112), but the eventual apology to the Stolen Generations (discussed below), had the effect of closing the political space opened up by the inquiry in a repeat of the settler's attempt to draw a line under the past.

The release of both the RCIADIC and Bringing Them Home reports occurred during Australia's formal decade of reconciliation, which is the second area of the administration of memory to be considered here. In response to Indigenous disappointment about the Hawke government's failure to advance a promised national treaty process, the government created the Council for Aboriginal Reconciliation (CAR) and set out the timeline for a formal, decade-long process, to conclude in 2001. The Minister for Aboriginal Affairs at this time, Robert Tickner, has since outlined what he saw as the three objectives for reconciliation in Australia. First, the need to educate non-Indigenous Australians about Aboriginal and Torres Strait Islander culture and the extent of disadvantage still experienced by Indigenous people. Second, the need for what Tickner-in an attempt to get away from the apparently polarizing language of 'treaty'-described as a 'document of reconciliation.' Through the formal reconciliation process Tickner hoped there could be some agreement on the terms of 
such a document and a further agreement on how it might be achieved. Finally, Tickner envisaged that reconciliation would build a social movement that would drive the nation to 'address indigenous aspirations, human rights and social justice' (Tickner, 2001).

Much of the ambition articulated by Tickner, and subsequently by the CAR, focused on Aboriginal and Torres Strait Islander aspirations for recognition of their sovereignty through a treaty or other document, and for political control and autonomy. Also prominent in these stated aims, however, was the recognition that non-Indigenous Australians required education about both Australia's history of injustice towards Indigenous peoples, and the contemporary impacts of these injustices in Aboriginal and Torres Strait Islander people's lives. As a result, considerable effort and expenditure on reconciliation in Australia was directed towards strategies designed to educate and engage non-Indigenous people. After ten years, however, it was difficult to observe much positive impact from the effort to educate the settler society. Indeed, over time it became clear that national reconciliation in Australia had minimal success in this regard. On the one hand, there is both anecdotal and survey evidence to show that the majority of non-Indigenous Australians supported the process and the aims of the CAR (Halloran, 2007, p. 2). Focus groups undertaken at the end of 1999 and the start of 2000 also found universal agreement that the position of Aboriginal people in Australia was a 'tragedy', and widespread agreement that Aboriginal people had been 'badly treated by the early white settlers' (Newspoll, Saulwick and Muller \& Mackay, 2000). At the same time, however, many people found it 'hard to face up to this,' with the more defensive participants in the research arguing that 'there was bad behavior on both sides.' There were 'few' who were 'inclined to see one side as the invader and the other as the invaded. Nor were there many who wished to accept any responsibility for what happened in what most saw as far-off days (Newspoll, Saulwick and Muller \& Mackay, 2000, p. 37). Indeed, as Angela Pratt has argued, while the formal reconciliation process in Australia did introduce a new and broad 'moral language' with which to speak about issues of Indigenous social justice, it did not help to resolve any these issues raised (Pratt, 2003, p. 157).

The 1996 election of the Howard government saw further significant change in government attitudes towards the aspirations of the reconciliation process, with more transformative ambitions explicitly rejected in favour of so-called 'practical 
reconciliation' that actively discounted the need to address past injustices (see Subašić and Reynolds, 2009). Renewed calls for a treaty were met with the Prime Minister's contention that 'an undivided nation does not make a treaty with itself' (Howard quoted in Sanders, 2005, p. 156). Overall, the period of the formal Australian reconciliation process came to be criticised for its 'intense resistance' to any decolonising action (Short, 2008, pp. 7, 36) and for effectively placing a 'colonial ceiling' on Indigenous aspirations by emphasising nation-building and national unity above all else (Short, 2008, p. 162). As in many other settler colonial states, the administration of memory through a formal reconciliation policy became a means of justifying rather than undoing colonial domination, and of closing rather than opening political space in which Aboriginal and Torres Strait Islander peoples and the settler state might engage over questions of their ongoing relationship.

One particular issue upon which the Australian reconciliation process foundered was on the Howard government's strenuous rejection of public calls to apologise to the Stolen Generations, the third and final area of the administration of memory to be considered in this article. Apologies remain a deeply symbolic means of publicly expressing responsibility and regret for past wrongs, particularly by political elites who are seeking to rebuild damaged relationships and respond to complex social issues (Verdeja, 2009, pp. 79, 83). As such, apologies have become 'a liberal marker of national political stability and strength rather than shame,' an effort by nations to demonstrate that they have to come to terms with their pasts (Barkan, 2000, p. xxix). Indeed, some consider apology to be the 'defining method of reconciliation politics,' transcending rather than satisfying the requirements of 'perfect justice' (Phillips, 2005, p. 119). In Australia, however, where an apology to the Stolen Generations was first recommended in the Bringing them Home report, the then prime minister's persistent rejection of this proposal had the effect of narrowing the terms of debate.

The 2008 apology was eventually delivered after a change of government in 2007, and with a clear prior statement from the new government that the apology would not be accompanied by any form of compensation to victims. The delivery of the apology was a response to a decade long campaign, beginning with a 'Sorry Day' held on the first anniversary of the release of the Bringing them Home report (which subsequently became an annual event), involving hundreds of community activities and the signing 
of the Sorry Books, which eventually collected hundreds of thousands of signatures in support of a national apology. Although this 'apology movement' continued to grow in subsequent years, it was not until the change of government in November 2007 that there was a firm commitment to proceed with a national apology. On 13 February 2008, during the first sitting of the new parliament, the new prime minister, Kevin Rudd made a moving speech in the House of Representatives acknowledging that:

The time has now come for the nation to turn a new page in Australia's history by righting the wrongs of the past and so moving forward with confidence to the future. We apologise for the laws and policies of successive Parliaments and governments that have inflicted profound grief, suffering and loss on these our fellow Australians. We apologise especially for the removal of Aboriginal and Torres Strait Islander children from their families, their communities and their country. For the pain, suffering and hurt of these Stolen Generations, their descendants and for their families left behind, we say sorry. To the mothers and the fathers, the brothers and the sisters, for the breaking up of families and communities, we say sorry. And for the indignity and degradation thus inflicted on a proud people and a proud culture, we say sorry (Rudd 2008).

For members of the Stolen Generations, and for many more in the settler society, the apology provided a moment of relief. However, the apology also demonstrated some significant shortcomings that are familiar to other apology initiatives elsewhere in the world. Firstly, despite significant consultation with Aboriginal and Torres Strait Islander peoples around Australia, the apology seemed designed to contribute to the nation-building agenda that many Aboriginal and Torres Strait Islander people reject, describing them as 'fellow Australians' rather than acknowledging their sovereignty, and omitting any reference to the genocide described in the Bringing them Home report, thus failing to adequately recognise the wider injustice perpetrated against them (Muldoon and Schaap, 2012, pp. 184, 188). This inadequacy was heightened by the government's refusal to even discuss the question of compensation. It has been widely acknowledged that where apologies are not accompanied by 'direct and immediate actions' (Minow, 1998, p. 116), or are otherwise without 'a practical component,' which may include paying compensation, they may amount to little more than a 'hollow 
symbolic statement' that does little to transform the status of victims and survivors (Verdeja, 2009, p. 82). In the Australian case, the failure to offer any kind of material reparations reflected a significant failure to acknowledge the political implications of child removal policies as a part of Australia's colonial, nation-building endeavour (Muldoon and Schaap, 2012, p. 188). Thus, in an important sense, the apology was used to strengthen rather than challenge the legitimacy of the settler state, leaving settler domination untroubled and possibly even strengthened through the maintenance of state authority to determine which Indigenous claims may be recognised (Balint and McMillan, 2014, pp. 209-10). Again, the settler colonial order sought to use the administration of memory to draw a line under Australia's colonial past and close down space for ongoing political engagement.

\section{An alternative response}

In light of these manifest shortcomings of the administration of memory in settler colonial Australian, this article proposes an alternative theoretical framework through which to pursue the administration of memory in settler colonial societies. Specifically, this framework draws on agonistic democracy theory (see Mouffe 2005, 2007) as a means of engaging the cycle of Indigenous-non-Indigenous contestation that I have argued is central to settler colonial political culture. As Ed Wingenbach (2011: 33 my emphasis) argues, 'the agonistic project emphasizes the creation of a symbolic space or regime of cultural intelligibility enabling citizens to engage in contestation without destroying the conditions of association that make community possible'. Thus, what differentiates an agonistic mode of engagement from a period such as the 'history war' described above is an attention to respectful dialogue rather than antagonistic contestation. The Australian history war was vicious and visceral, and its very nastiness effectively closed down political space — who, after all, would risk reputation, career, or some other form of public humiliation in order to engage in dialogue about history under such conditions?

It is useful, then to consider the features that Bull and Hansen (2016: 399) ascribe to an 'agonistic mode of remembering', which attend precisely to the creation of the symbolic political space for dialogue. Bull and Hansen outline these features as including behaviours that avoid pitting 'good' against 'evil'; rely on testimony from those on all sides of a contested memory (i.e. 'victims, 'perpetrators', and 'bystanders'); recognise 
the importance of emotions in these spaces; and reconstruct the contexts, struggles, and multiple narratives that contributed to mass crimes and historic wrongs. Attending to these features allow an agonistic approach to memory to be 'both reflexive and dialogic' (Bull and Hansen 2016: 400) while also preserving the conditions of association that make discussion of the past a possibility in policy discourse.

Such an agonistic approach would enable a move away from the settler desire for the 'completion' of the colonial project. Settler narratives focus on a 'moment of political break' - a moment in which some form of memory policy, such as recognition, inclusion or apology, allows the settler state to 'separate the tolerant, inclusive present from the exclusive, colonial past' (Strakosch, 2015, p. 21). In this mode, the administration of memory produces national narratives that create a kind of 'inwardlooking invisibility' in which the settler state seems unable to see the violence, destruction, and racism upon which the society is created and maintained (Battell Lowman and Barker, 2015, p. 3). Even as policy actors imagine that the effective administration of memory will allow the nation to move towards a more peaceful, equitable, and reconciled future, the reality is that settler colonialism persists in structure and policy. The settler's effort to draw a line under the past will inevitably fail. In light of this, it is evident that the settler desire to achieve colonial 'completion' through the administration of memory will always prove limited, disappointing, and ineffectual.

By contrast an agonistic approach offers the chance to engage with the conflictual dynamics that are inherent to the administration of memory in settler colonial societies by prescribing only that antagonists (Indigenous peoples and settlers) prioritise the creation and maintenance of political space in which contested versions of history can co-exist. An agonistic approach to the administration of memory underscores the openended nature of reconciliation efforts, allowing that the past can always be revisited and reanalyzed, and countering suggestions that the work of reconciliation is ever complete. Creating space in which a multiplicity of perspectives is given voice, and in which the full complexity of historical events can be engaged, is more aligned with the endless contestation of historical memory in settler societies. 
An agonistic approach acknowledges that memory is rarely held consensually but is more often the product of significant contestation (Gibson 2004, p. 70). For example, bringing an agonistic perspective to truth telling processes assumes from the outset that such a process will not lead to the discovery of one 'truth' but will instead allow the process to focus on engaging conflicting historical accounts through dialogue intended to 'make a conflict more liveable' (Little, 2014, p. 100). As in the Australian case (inter alia) the 'contested historical terrain' that results from any process of truth telling is likely to involve rigorous debate over both the facts and implications of past actions, such as in the Australian 'history wars' (Muldoon, 2008, p. 128). As Schaap (2005, p. 84), contends, 'the faith of political reconciliation is that, by engaging in incessant discourse about the world that lies between former enemies, this world might appear more common to them.'

An agonistic approach to the administration of memory also recognises that although reconciliation tends to be oriented towards consensus and closure, this goal is both unrealistic and undesirable. Schaap (2006, p. 258) has argued that an agonistic approach to reconciliation is important because it foregrounds what is at stake in the politics of these processes. He contends that less critical accounts of reconciliation that emphasise ideas of 'settling accounts', 'healing nations' and 'restoring community' start from the presumption that unity is an unquestioned social good, thereby depoliticising the terms in which the unity of the polity is constructed and represented. Further, as has been argued above, this desire to draw a line under the past through the administration of memory serves the interests of settler colonial states at the expense of Indigenous desires to keep the past alive in the present. Indeed, as Muldoon (2008, p. 127) has suggested, an agonistic perspective makes it possible to understand how reconciliation makes it onto the political agenda; not because there is sudden agreement about past wrongs, but because marginalised groups politicise those past actions by renaming them as injustices. The challenge in these contexts, according to Charles Villa-Vicencio (2009, p. 62) is 'to develop ways of engagement that allow for nonconformity, dissent, open debate, and orderly political change when necessary.' When the desire to pursue an endpoint to reconciliation can be avoided, and it can instead be maintained as an 'open horizon', a more agonistic approach to the administration of memory has the capacity to sustain politics in divided societies (Schaap, 2005, p. 84). 
An agonistic approach may also steer the administration of memory away from a teleological view of the past oriented only towards a 'better', more inclusive future. Indigenous cultural differences tend to be excluded from 'the national imaginary' (Bashir and Kymlicka 2008, pp. 11-12) of the settler colonial state; an element of the logic of settler colonialism that pursues the eradication of Indigenous peoples through assimilation and coercion to live more Westernised lives. An agonistic orientation to the administration of memory may counter the settler desire to 'include' Indigenous peoples in a unified nation with a shared national identity, language, and public culture that risks repeating the assimilationist drive.

Settlers also have much at stake in the administration of memory in settler colonial societies. The denunciation of the so-called 'black armband' view of Australian history belied the settler's fear of 'being cast out', either through the direct loss of land or through the loss of legitimacy in the continued occupation of unceded Indigenous territory (Curthoys, 2003, p. 198). The vehemence of the settler's rejection of Indigenous claims about past injustice reveals the defensiveness of a dominant community that, after several generations of territorial occupation, has "nowhere else to belong' (Cavanagh, 2012, p. 39). The settler's need to belong to the land drives a need to cover up or minimise the nature of their arrival and the dispossession of Indigenous peoples from their lands. Australian national identity risks losing its 'powerful anchor' in the landscape (Cowlishaw, 2004, pp. 5-6) along with the 'familiar and comforting map of the past' (Attwood and Foster, 2003, p. 13) that promotes a view of settler egalitarianism and benevolence. A more agonistic approach to the administration of memory, that brings in multiple perspectives as per Bull and Hansen's framing, allows for these fears to be surfaced and brought into dialogue with Indigenous views, rather than repressed, only to resurface in ways that undermine the potential for less oppressive social relations.

An agonistic approach to memory policy does not foreclose the possibility that settler societies and Indigenous peoples can together build interpretations of the past that both parties can share, and in which there is space to negotiate identities and mediate national histories. But neither would it push towards such an achievement in the way that settleroriented policies of reconciliation seem to dictate. Reconceiving of such policy as a form of ongoing dialogue, however, rather than pursuing a moment of colonial 
completion in which all such matters are resolved, involves a significant shift in thinking about the work that policy can do. Historical violence, marginalisation and oppression have shaped Indigenous and settler identities in terms of opposition and conflict (Bashir, 2008, pp. 49, 53). Agonistic memory does not deny or evade this reality. Rather it seeks spaces and forms of engagement that attend to the reality of settler colonial coexistence.

\section{Conclusion}

Questions of how to deal with the past through the administration of memory are contested in all societies - stable democracies as well as countries attempting to overcome recent conflict - and go beyond the recording of an official history. In debates over policy, counter-narratives of historical memory seek to replace narratives that have been controlled by elites, contesting hegemonic and institutionalised accounts of a nation's history. These counter-narratives refuse to allow past injustice to be excused as incidental to the nation-building agenda. Policies that seek to engage with a nation's memory of the past tend therefore to be made in a contested and politically fraught environment. This is nowhere more true than in contemporary settler colonial societies such as Australia.

The way we deal with the past is not confined to the history books but is a deeply political process that is very much the business of contemporary public administration. There are choices to be made about the way to engage in 'memory politics' (Seider, 2003 , p. 210) that will in turn shape the ways in which the recognition of past harms can re-write aspects of history and re-shape the ground on which we stand (Ahmed, 2005, p. 83). Although individual memories are not something to be commanded by policy, settler colonial states can make choices about what and how they publicly remember, what they attempt to forget or eradicate, and how they might engage the inevitable conflicts involved in these processes. An agonistic approach to the administration of memory will often involve be uncomfortable for needs to be free from the platitudes about unity and harmony that generally tend to inform reconciliation work. Learning to live with this discomfort, developing policies and processes that do not deny the conflicts that persist in settler colonies, is an essential if challenging task. 


\section{References}

Ahmed, S. (2005). The politics of bad feeling. Australian Critical Race and Whiteness Studies Association Journal, 1, 72-85.

Arthur, P. (2012). Indigenous Self-Determination and Political Rights: Practical Recommendations for Truth Commissions. Strengthening Indigenous Rights Through Truth Commissions: A Practitioner's Resource, New York: International Center for Transitional Justice.

Attwood, B. and Foster, S. (2003). Eds. Frontier conflict: The Australian experience. Canberra: National Museum of Australia.

Balint, J., Evans, J. and McMillan, N. (2014). Rethinking transitional justice, redressing indigenous harm: A new conceptual approach. International Journal of Transitional Justice, 8(1).

Barkan, E. (2000). The guilt of nations: Restitution and negotiating historical injustices. Baltimore: The Johns Hopkins University Press.

Bashir, B. (2008). Accommodating historically oppressed social groups: Deliberative democracy and the politics of reconciliation. In Will Kymlicka and Bashir Bashir (Eds) The politics of reconciliation in multicultural societies (48-69). Oxford: Oxford University Press.

Bashir, B. and Kymlicka, W. (2008). Introduction: Struggles for Inclusion and Reconciliation in Modern Democracies. In Will Kymlicka and Bashir Bashir (eds) The Politics of Reconciliation in Multicultural Societies, Oxford: Oxford University Press.

Battell Lowman, E. and Barker, A.J. (2015), Settler: Colonialism and Identity in $21^{\text {st }}$ Century Canada. Halifax: Fernwood Press.

Bhandar, B. (2007). 'Spatializing history' and opening time: Resisting the reproduction of the proper subject. In Scott Veitch (Ed.) Law and the politics of reconciliation. Aldershot: Ashgate Publishing Ltd. 
Birch, T. (2007).'The invisible fire': Indigenous sovereignty, history and responsibility. In A. Moreton-Robinson (Ed.) Sovereign subjects: Indigenous sovereignty matters. Crows Nest: Allen and Unwin

Bull, A. C. and Hansen, H. L. (2016), 'On agonistic memory', Memory Studies, 9(4), $390-404$

Cavanagh, E. (2012). History, time and the indigenist critique. Arena Journal, no. $37 / 38$

Cowlishaw, G. (2004). Blackfellas, whitefellas and the hidden injuries of race. Malden MA: Blackwell.

Curthoys, A. (2003). Constructing national histories. In Bain Attwood and Stephen Foster, Stephen Eds. Frontier conflict: The Australian experience (185-200).

Canberra: National Museum of Australia.

Gunstone, A. (2009). Unfinished business: The Australian formal reconciliation process, Second edition. Melbourne: Australian Scholarly Publishing.

Halloran, M. J. (2007). Indigenous reconciliation in Australia: Do values, identity and collective guilt matter? Journal of Community and Applied Social Psychology, 17, 118.

Hamber, B. (2012). Transitional justice and intergroup conflict. In L.R. Tropp (Ed.) The Oxford handbook of intergroup conflict. New York: Oxford University Press.

Henderson, A. (2016). Pat Dodson: Aboriginal leader sounds renewed warning on 'vicious cycle' of deaths in custody. ABC News, 13 April http://www.abc.net.au/news/2016-04-13/aboriginal-deaths-in-custody-worse-25years-on/7322872

Howard, J. (1996). Transcript of the prime minister-elect the Hon. John Howard MP: Press conference. Sydney.

Howard-Wagner, D. (2012). Reclaiming the Northern Territory as a settler-colonial space/ Arena Journal, 37/38, 220-240. 
Human Rights and Equal Opportunities Commission. (1997, now the Australian Human Rights Commission). Bringing Them Home: Report of the National Inquiry into the Separation of Aboriginal and Torres Strait Islander Children from Their Families, Sydney: Australian Human Rights Commission.

Jung, C. (2011). Canada and the Legacy of the Indian Residential Schools: Transitional Justice for Indigenous People in a Nontransitional Society. In Paige Arthur (ed.) Identities in Transition: Challenges for Transitional Justice in Divided Societies. New York: Cambridge University Press.

Kymlicka, W. (2011). Transitional Justice, Federalism, and the Accommodation of Minority Nationalism. In Paige Arthur (Ed.) Identities in Transition: Challenges for Transitional Justice in Divided Societies. New York: Cambridge University Press.

Leebaw, B. A. (2008). The Irreconcilable Goals of Transitional Justice. Human Rights Quarterly 30(1)

Little, A. (2014). Enduring conflict: Challenging the signature of peace and democracy. New York: Bloomsbury Publishing.

Macintyre, S. and Clark, A. (2003). The History Wars. Melbourne: Melbourne University Press.

Macoun, A. and Strakosch, E. (2013). The ethical demands of settler colonial theory. Settler Colonial Studies, 3(3-4), 426-443.

McGregor, R. (2011). Indifferent inclusion: Aboriginal people and the australian nation. Canberra: Aboriginal Studies Press.

Maddison, S. (2016). Settler Australia in the twentieth century. In E. Cavanagh, and L. Veracini (Eds), The Routledge history of settler colonialism. London: Routledge. Maddison, S. (2011). Beyond White Guilt: The Real Challenge for Black-White Relations in Australia. Sydney: Allen and Unwin.

Maddison, S. and Shepherd, L. J. (2014). 'Peacebuilding and the postcolonial politics of transitional justice. Peacebuilding, 2(3), 253-269. 
Manne, R. (2001). In Denial: The Stolen Generation and the Right. Quarterly Essay, no. 1.

Manne, R. (2003). (ed), Whitewash: On Keith Windschuttle's Fabrication of Aboriginal History. Melbourne: Black Inc.

Minow, M. (1998). Between vengeance and forgiveness: Facing history after genocide and mass violence. Boston: Beacon Press.

Mouffe, C. (1999). Deliberative Democracy or Agonistic Pluralism? Social Research, 66(3), 745-758.

Mouffe, C. (2007). 'Democracy as agonistic pluralism', in E.D. Ermath (ed) Rewriting democracy: Cultural politics in postmodernity, Aldershot: Ashgate.

Mouffe, C. (2005). On the political. London: Routledge

Muldoon, P. (2005). Thinking Responsibility Differently: Reconciliation and the Tragedy of Colonization. Journal of Intercultural Studies 26(3)

Muldoon, P. and Schaap, A. (2012). Confounded by recognition: The apology, the High Court and the Aboriginal Embassy in Australia. In A. K. Hirsch (ed.), Theorizing post-conflict reconciliation. London: Routledge

Newspoll, Saulwick, I., Muller, D., \& Mackay, H. (2000). Public opinion on Reconciliation: Snap shot, close focus, long lens. In M. Grattan (Ed.), Reconciliation: Essays on Australian Reconciliation (33-52). Melbourne: Black Inc.

Phillips, M. (2005). Aboriginal reconciliation as religious politics: Secularisation in Australia. Australian Journal of Political Science, 40(1), 111-124.

Pratt, A. (2003). Practising reconciliation? The politics of reconciliation in the Australian parliament, 1991-2000, Parliamentary Library, Parliament of Australia, Canberra.

Razack, S. (2015). Dying from improvement: Inquests and inquiries into Indigenous deaths in custody. Toronto: University of Toronto Press. 
Renner, J. (2012). A Discourse Theoretical Approach to Transitional Justice Ideals:

Conceptualising "Reconciliation" as an Empty Universal in Times of Political

Transition. In Nicola Palmer, Phil Clark and Danielle Granville (Eds) Critical

Perspectives in Transitional Justice. Cambridge: Intersentia Publishing.

Reynolds, H. (2013). Forgotten war. Sydney: New South Publishing

Reynolds, H. (1999). Why weren't we told? A personal search for the truth about our history. Melbourne: Viking.

Rose, D. B. (2004). Reports from a wild country: Ethics for decolonisation. Sydney: UNSW Press.

Royal Commission into Aboriginal Deaths in Custody (1991).

http://www.austlii.edu.au/au/other/IndigLRes/rciadic/

Rudd, K. (2008). Apology to Australia's Indigenous peoples. Canberra: House of Representatives, Parliament House. 13 February

Sanders, W. (2005). Never even adequate: Reconciliation and Indigenous affairs. In

C. Aulich and R. Wettenhall (Eds) Howard's second and third governments: Australian Commonwealth Administration 1998-2004,(152-172). Sydney: UNSW Press.

Schaap, A. (2006). Agonism in divided societies. Philosophy \& Social Criticism. 32(2) 255-277.

Schaap, A. (2005). Political reconciliation, London: Routledge.

Seider, R. (2003). War, peace and the politics of memory in Guatemala. In Nigel Biggar (Ed) Burying the past: Making peace and doing justice after civil conflict (209-234). Washington D.C.: Georgetown University Press.

Short, D. (2008). Reconciliation and colonial power: Indigenous rights in Australia. Aldershot: Ashgate

Short, D. (2005). 'Reconciliation and the problem of internal colonisation', Journal of Intercultural Studies. 26(3) 267-282 
Strakosch, E. (2015). Neoliberal Indigenous policy: Settler colonialism and the 'postwelfare'state. Basingstoke: Palgrave Macmillan.

Strakosch, E. and Macoun, A. (2012). The Vanishing Endpoint of Settler Colonialism. Arena Journal, 37/38

Subašić, E. and Reynolds, K. (2009). Beyond "Practical” Reconciliation: Intergroup Inequality and the Meaning of Non-Indigenous Identity. Political Psychology, 30(2), 243-267.

Tickner, R. (2001). Taking a stand: Land rights to reconciliation. Sydney: Allen \& Unwin.

Verdeja, E. (2009). Unchopping a tree: Reconciliation in the aftermath of political violence. Philadelphia: Temple University Press.

Villa-Vicencio, C. (2009). Walk with us and listen: Political reconciliation in Africa, Washington D.C.: Georgetown University Press.

Windschuttle, K. (2002). The Fabrication of Aboriginal History, Volume One: Van Diemen's Land 1803-1847 Sydney: Macleay Press.

Wolfe, P. (2016). Traces of history: Elementary structures of race. London: Verso.

Wolfe, P. (1999). Settler Colonialism and the Transformation of Anthropology: The Politics and Poetics of an Ethnographic Event. London: Cassell.

Woolford, A. (2010). Genocide, affirmative repair, and the British Columbia Treaty Process. In A.L. Hinton (Ed.) Transitional justice: Global mechanisms and local realities after genocide and mass violence. New Brunswick: Rutgers University Press. 


\section{University Library}

\section{- M M N E R VA A gateway to Melbourne's research publications}

Minerva Access is the Institutional Repository of The University of Melbourne

Author/s:

Maddison, $S$

Title:

The Limits of the Administration of Memory in Settler Colonial Societies: the Australian Case

Date:

2019-06-01

Citation:

Maddison, S. (2019). The Limits of the Administration of Memory in Settler Colonial

Societies: the Australian Case. INTERNATIONAL JOURNAL OF POLITICS CULTURE AND SOCIETY, 32 (2), pp.181-194. https://doi.org/10.1007/s10767-018-9303-0.

Persistent Link:

http://hdl.handle.net/11343/292087 